Journal of Elemantary School (JOES)

Volume 1, Nomor 1, Juni 2018

e-ISSN : 2615-1448

p-ISSN : 2620-7338

DOI : https://doi.org/10.31539/joes.v1i1.261

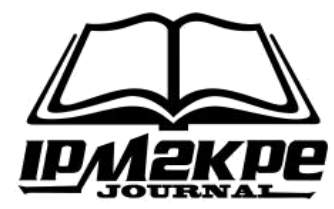

\title{
UPAYA MENINGKATKAN HASIL BELAJAR SISWA PADA MATERI PEMBENTUKAN TANAH KARENA PELAPUKAN BATUAN DENGAN MODEL KOOPERATIF TIPE TWO STAY TWO STRAY DI KELAS VI SD NEGERI 39 LUBUKLINGGAU
}

\author{
Nurbayati \\ SD Negeri 39 Lubuklinggau \\ nurbayati2018@gmail.com
}

\begin{abstract}
ABSTRAK
Tujuan penelitian ini bermaksud memperbaiki pembelajaran dengan mengadakan penelitian tindakan kelas yang terdiri dari tiga siklus dengan menggunakan Model Kooperatif Tipe Two Stay Two Stray. Pelaksanaan penelitian dilakukan prasiklus pada tanggal 2 Februari 2015, siklus 1 pada tanggal 9 Februari 2015, dan siklus 10 Februari 2015 dengan hasil sebagai berikut: pertama keaktifan siswa dari prasiklus, siklus 1 dan siklus 2 mengalami kemajuan yaitu pada prasiklus 56,67\%, siswa yang aktif pada siklus 1 meningkat menjadi 70\% dan siklus 2 menjadi 86,67\% siswa yang aktif. Kedua rata-rata tes yang diadakan pada tiap siklus juga mengalami kenaikan yang signifikan yaitu prasiklus rata-rata hanya 51,83, pada siklus 1 meningkat menjadi 62,5 dan pada siklus 2 menjadi 80,83. Ketuntasan juga mengalami kenaikan pada prasiklus hanya 43,33\%, siklus 1 meningkat menjadi $66,67 \%$, dan pada siklus 2 mencapai 93,33\%. Jadi dapat disimpulkan penggunaan model kooperatif tipe Two Stay Two Stray berhasil meningkatkan kemampuanyang mendorong prestasi belajar siswa khususnya Kelas VI SD Negeri 39 Lubuklinggau.
\end{abstract}

Kata Kunci: Hasil Belajar, Model TSTS

\section{ABSTRACT}

The low level of activity of grade 6 students of SD Negeri 39 Lubuklinggau in science lesson, and the learning model used is less varied resulting in low student learning outcomes in science lesson, therefore the researcher intends to improve learning by conducting classroom action research consisting of three cycles by using Model Cooperative Type Two Stay Two Stray. The study was conducted on February 2, 2015, cycle 1 on February 9, 2015, and cycle of 10 February 2015 with the following results: first activity of students from prasiklus, cycle 1 and cycle 2 progressed on prasiklus $56.67 \%$, students active in cycle 1 increased to $70 \%$ and cycle 2 to $86.67 \%$ of active students. Both the average test held in each cycle also experienced a significant increase of average prasiklus only 51.83, in cycle 1 increased to 62.5 and in cycle 2 to 80.83. Completeness also experienced an increase in prasiklus only $43.33 \%$, cycle 1 increased to $66.67 \%$, and in cycle 2 reached $93.33 \%$. So it can be concluded the use of cooperative model type Two Stay Two Stray managed to 
improve the ability to encourage student achievement, especially Class VI SD Negeri 39 Lubuklinggau.

Keywords: Learning Outcomes, TSTS Model

\section{PENDAHULUAN}

Pendidikan adalah bidang yang sangat penting bagi suatu negara berkembang seperti Indonesia, sebab kemajuan dan masa depan bangsa terletak sepenuhnya pada kemampuan anak didik dalam membaca dan mengikuti kemajuan pengetahuan dan teknologi dengan segala kemudahan. Pada masa yang akan datang, penguasaan dunia tidak lagi hanya tergantung kepada sumber daya alam, tetapi sangat dipengaruhi oleh tersedianya sumber daya manusia yang tangguh, berpengetahuan luas, kreatif, terampil dan berkepribadian (Khaliq, 2009). Dengan adanya pendidikan maka akan tercipta sumber daya manusia yang memiliki kekuatan spiritual keagamaan, kepribadian, kecerdasan, akhlak mulia, serta keterampilan yang diperlukan dirinya dan masyarakat. Hal ini dikarenakan dalam pendidikan akan diperoleh berbagai informasi dan ilmu pengetahuan serta pengembangan potensi diri.

Salah satu ilmu pengetahuan dalam pendidikan yaitu ilmu pengetahuan Alam. Ilmu Pengetahuan Alam adalah penyelidikan yang terorganisir untuk mencapai pola atau keteraturan dalam alam (Hanifah, 2009). Ilmu Pengetahuan Alam sebagai produk tidak dapat dipisahkan dari hakikatnya sebagai proses. Sehingga membutuhkan pemahaman secara bertahap dan berurutan. Mata pelajaran IPA merupakan suatu sistem pelajaran yang memicu siswa untuk berpikir kritis karena didalamnya terdapat unsur fakta, konsep, dan prinsip Oleh karena itu diperlukan komponen- komponen yang dapat menunjang yaitu tujuan, materi, strategi belajar mengajar dan evaluasi. Masing-masing komponen ini saling memenuhi satu sama lain. Jadi komponen pembelajaran tersebut harus diperhatikan oleh guru dalam menentukan model pembelajaran yang akan digunakan dalam kegiatan pembelajaran. Model pembelajaran dapat dijadikan pola pilihan, artinya para guru boleh memilih model pembelajaran yang sesuai dan efisien dengan materi yang ada untuk mencapai tujuan pembelajaran (Rusman, 2010).

Salah satu tujuan mata pelajaran IPA dalam lampiran peraturan Mendiknas Nomor 22 Tahun 2006 adalah mengembangkan keterampilan proses untuk menyelidik alam sekitar, memecahkan masalah dan membuat kesimpulan. Dengan mengkaji tujuan mata pelajaran IPA tersebut guru hendaknya memilih dan menggunakan sistem pengajaran yang sistematis dan dapat melibatkan siswa berperan aktif dalam kegiatan pembelajaran (Suprijono, 2009). Sehingga siswa termotivasi untuk belajar. Oleh karena itu, variasi dalam memilih model 
pembelajaran sangat penting agar dapat mencapai tujuan pembelajaran yang telah direncanakan.

\section{METODE PENELITIAN}

Penelitian dilaksanakan di kelas VI SD Negeri 39 Lubuklinggau dengan jumlah siswa sebanyak 30 orang terdiri dari 19 orang laki-laki dan 11 orang perempuan. Mereka rata-rata berusia antara 10 sampai 11 tahun. Penelitian dilakukan secara kolaboratif yaitu antara guru yang berperan sebagai pelaku tindakan dengan penilai 1 dan penilai 2 sebagai observer. Adapun waktu pelaksanaan perbaikan pembelajaran ini. Prasiklus pada tanggal 2 Februari 2015, siklus 1 pada tanggal 9 Februari 2015 dan siklus 2 pada tanggal 10 Februari 2015. Desain prosedur perbaikan pembelajaran dilakukan melalui penelitian tindakan kelas (PTK) yang terdiri atas dua siklus. Setiap siklus kegiatan yang dilakukan meliputi:perencanaan, pelaksanaan, observasi/pengamatan, dan refleksi (Pribadi, 2009).

Dalam menganalisis data, penulis menggunakan teknik analisis statistik deskriptif kualitatif dan statistik kuantitatif. Statitik kualitatif adalah pengumpulan dan penyajian data dibuat dalam bentuk uraian yang disajikan dalam lembar observasi, tabel dan grafik. Sedangkan data deskriptif kuanttatif adalah data yang dianalisis untuk menemukan persentase dan nilai rata-rata, dapat disajikan dalam bentuk tabel distribusi atau grafik. Untuk mengetahui skala keberhasilan siswa, penulis menggunakan rumus:

Rata-rata $(\bar{x})=\frac{\text { total skor perolehan seluruh siswa }}{\text { Jumlah Siswa }}, \bar{x}$ berhasil $\geq 60$

Siswa tuntas belajar (individu) dengan nilai akhir $\geq 60$ (KKM).

Tuntas materi pembelajaran berdasarkan ketuntasan klasikal $\geq 85 \%$ dengan rumus:

Persentase klasikal $(\mathrm{PK})=\frac{\text { Jumlah siswa tuntas }}{\text { Jumlah seluruh Siswa }} \times 100 \%$

Persentase keberhasilan keaktifan siswa dihitung dari nilai observasi $\geq 80 \%$ yang aktif.

\section{HASIL PENELITIAN}

\section{Hasil Observasi}

Hasil observasi yang dilakukan guru dan supervisor 2 terhadap siswa dari sebelum perbaikan dan setelah perbaikan pembelajaran tersaji pada tabel berikut ini: 
Tabel 1

Hasil Pengamatan Aktivitas Siswa

\begin{tabular}{cccccccc}
\hline \multirow{2}{*}{ No } & Minat Belajar & \multicolumn{2}{c}{ Pra Siklus } & \multicolumn{2}{c}{ Siklus 1 } & \multicolumn{2}{c}{ Siklus 2 } \\
\cline { 3 - 8 } & $\begin{array}{c}\text { Jumlah } \\
\text { Siswa }\end{array}$ & $\%$ & $\begin{array}{c}\text { Jumlah } \\
\text { Siswa }\end{array}$ & \multicolumn{3}{c}{$\begin{array}{c}\text { Jumlah } \\
\text { Siswa }\end{array}$} \\
\hline 1 & Terlibat Aktif & 17 & $56,67 \%$ & 21 & $70 \%$ & 26 & $86,67 \%$ \\
\hline 2 & Terlibat Pasif & 5 & $16,67 \%$ & 4 & $13,33 \%$ & 3 & $10 \%$ \\
\hline 3 & Tidak Terlibat & 8 & $26,67 \%$ & 5 & $16,67 \%$ & 1 & $3,3 \%$ \\
\hline & Jumlah & 30 & $100 \%$ & 30 & $100 \%$ & 30 & $100 \%$ \\
\hline
\end{tabular}

Keterangan:

Terlibat aktif, artinya siswa menyimak dengan sungguh-sunguh mengajukan pertanyaan, mampu menjawab pertanyaan dengan benar, ikut aktif berdiskusi dan berani mengeluarkan pendapat. Terlibat pasif, artinya siswa menyimak dengan sungguh-sungguh, menjawab pertanyaan tetapi belum tentu benar dan ikut berdiskusi. Tidak terlibat, artinya siswa tidak mau bertanya, tidak menjawab dan diam saja.

Berdasarkan tabel 1 di atas terlihat bahwa jumlah siswa dan persentase siswa yang aktif dalam pembelajaran menunjukkan adanya peningkatan. Hal ini terbukti pada prasiklus siswa yang terlibat aktif hanya 17 orang $(56,67 \%)$, kemudian pada siklus 1 meningkat menjadi 21 orang $(70 \%)$ dan pada siklus 2 meningkat lagi menjadi 26 orang $(86,67 \%)$. Peningkatan aktivitas belajar siswa sebelum perbaikan dan pada siklus perbaikan pembelajaran lebih jelas tersaji pada gambar 2 di bawah ini.

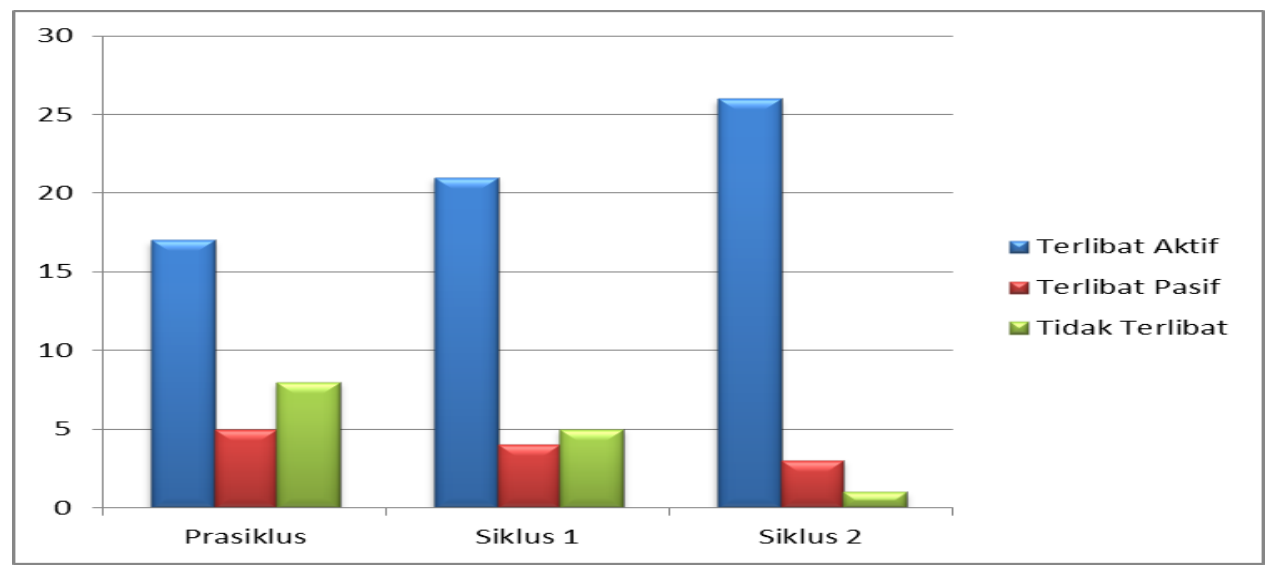

Grafik 1. Aktivitas Belajar Siswa

\section{Hasil Evaluasi}

Hasil evaluasi yang dilakukan guru dalam pembelajaran IPA selama prasiklus tersaji pada tabel 2 berikut. 
Tabel 2

\section{Hasil Belajar Siswa}

\begin{tabular}{|c|c|c|c|c|}
\hline \multirow[b]{2}{*}{ No } & \multirow[b]{2}{*}{ Nama } & \multirow{2}{*}{$\begin{array}{l}\text { Nilai } \\
\text { Prasiklus }\end{array}$} & \multicolumn{2}{|c|}{ Ketuntasan } \\
\hline & & & Tuntas & $\begin{array}{l}\text { Tidak } \\
\text { Tuntas }\end{array}$ \\
\hline 1 & Aprianto & 65 & $\sqrt{ }$ & \\
\hline 2 & Aldi & 45 & & $\sqrt{ }$ \\
\hline 3 & Arafik & 40 & & $\sqrt{ }$ \\
\hline 4 & Ahmad & 70 & $\sqrt{ }$ & \\
\hline 5 & Aliah & 35 & & $\sqrt{ }$ \\
\hline 6 & Ajai Gustian & 25 & & $\sqrt{ }$ \\
\hline 7 & Della & 75 & $\sqrt{ }$ & \\
\hline 8 & Dafid & 65 & $\sqrt{ }$ & \\
\hline 9 & Defri & 50 & & $\sqrt{ }$ \\
\hline 10 & Dimas & 75 & $\sqrt{ }$ & \\
\hline 11 & Elmansyah & 25 & & $\sqrt{ }$ \\
\hline 12 & Elmarani & 35 & & $\sqrt{ }$ \\
\hline 13 & Edi Santoso & 45 & & $\sqrt{ }$ \\
\hline 14 & Firdaus & 50 & & $\sqrt{ }$ \\
\hline 15 & Frem Kusumo & 65 & $\sqrt{ }$ & \\
\hline 16 & Firmansyah & 25 & & $\sqrt{ }$ \\
\hline 17 & Holid & 60 & $\sqrt{ }$ & \\
\hline 18 & Intan & 75 & $\sqrt{ }$ & \\
\hline 19 & Putri Jelita & 40 & & $\sqrt{ }$ \\
\hline 20 & Pina Anvaim & 75 & $\sqrt{ }$ & \\
\hline 21 & Rizki & 65 & $\sqrt{ }$ & \\
\hline 22 & M. Sandi & 35 & & $\sqrt{ }$ \\
\hline 23 & Redi Yansyah & 45 & & $\sqrt{ }$ \\
\hline 24 & Sri Yuyun & 25 & & $\sqrt{ }$ \\
\hline 25 & Shinta Bella & 70 & $\sqrt{ }$ & \\
\hline 26 & Samsiah & 70 & $\sqrt{ }$ & \\
\hline 27 & Selci & 50 & & $\sqrt{ }$ \\
\hline 28 & Verdi & 40 & & $\sqrt{ }$ \\
\hline 29 & Tina Lestari & 60 & $\sqrt{ }$ & \\
\hline \multirow[t]{5}{*}{30} & Wahyu & 55 & & $\sqrt{ }$ \\
\hline & Jumlah & 1555 & & \\
\hline & Rata-rata Kelas & 51,83 & & \\
\hline & Nilai Terendah & 25 & & \\
\hline & Nilai Tertinggi & 75 & & \\
\hline \multirow{2}{*}{ Tuntas } & Jumlah Anak & 30 & 13 & 17 \\
\hline & Presentase & & $43,33 \%$ & $56,67 \%$ \\
\hline
\end{tabular}


Dari tabel 2 di atas hasil prasiklus jumlah anak yang tuntas atau mendapat $\geq$ 60 sebanyak 13 siswa atau sebesar 43,33\% sedangkan yang belum tuntas sebanyak 17 siswa atau sebesar 56,67\%, serta nilai rata-rata kelas hanya mencapai 51,83.

Tabel 3

Hasil Belajar Siswa

\begin{tabular}{|c|c|c|c|c|}
\hline \multirow[b]{2}{*}{ No } & \multirow[b]{2}{*}{ Nama } & \multirow{2}{*}{$\begin{array}{l}\text { Nilai } \\
\text { Siklus } 1\end{array}$} & \multicolumn{2}{|c|}{ Ketuntasan } \\
\hline & & & Tuntas & $\begin{array}{l}\text { Tidak } \\
\text { Tuntas }\end{array}$ \\
\hline 1 & Aprianto & 65 & $\sqrt{ }$ & \\
\hline 2 & Aldi & 45 & & $\sqrt{ }$ \\
\hline 3 & Arafik & 70 & $\sqrt{ }$ & \\
\hline 4 & Ahmad & 85 & $\sqrt{ }$ & \\
\hline 5 & Aliah & 70 & $\sqrt{ }$ & \\
\hline 6 & Ajai Gustian & 55 & & $\sqrt{ }$ \\
\hline 7 & Della & 75 & $\sqrt{ }$ & \\
\hline 8 & Dafid & 65 & $\sqrt{ }$ & \\
\hline 9 & Defri & 50 & & $\sqrt{ }$ \\
\hline 10 & Dimas & 75 & $\sqrt{ }$ & \\
\hline 11 & Elmansyah & 35 & & $\sqrt{ }$ \\
\hline 12 & Elmarani & 50 & & $\sqrt{ }$ \\
\hline 13 & Edi Santoso & 45 & & $\sqrt{ }$ \\
\hline 14 & Firdaus & 65 & $\sqrt{ }$ & \\
\hline 15 & Frem Kusumo & 65 & $\sqrt{ }$ & \\
\hline 16 & Firmansyah & 55 & & $\sqrt{ }$ \\
\hline 17 & Holid & 60 & $\sqrt{ }$ & \\
\hline 18 & Intan & 75 & $\sqrt{ }$ & \\
\hline 19 & Putri Jelita & 40 & & $\sqrt{ }$ \\
\hline 20 & Pina Anvaim & 80 & $\sqrt{ }$ & \\
\hline 21 & Rizki & 75 & $\sqrt{ }$ & \\
\hline 22 & M. Sandi & 65 & $\sqrt{ }$ & \\
\hline 23 & Redi Yansyah & 45 & & $\sqrt{ }$ \\
\hline 24 & Sri Yuyun & 50 & & $\sqrt{ }$ \\
\hline 25 & Shinta Bella & 70 & $\sqrt{ }$ & \\
\hline 26 & Samsiah & 70 & $\sqrt{ }$ & \\
\hline 27 & Selci & 60 & $\sqrt{ }$ & \\
\hline 28 & Verdi & 70 & $\sqrt{ }$ & \\
\hline 29 & Tina Lestari & 75 & $\sqrt{ }$ & \\
\hline \multirow[t]{5}{*}{30} & Wahyu & 70 & $\sqrt{ }$ & \\
\hline & Jumlah & 1875 & & \\
\hline & Rata-rata Kelas & 62,5 & & \\
\hline & Nilai Terendah & 35 & & \\
\hline & Nilai Tertinggi & 85 & & \\
\hline \multirow{2}{*}{ Tuntas } & Jumlah Anak & 30 & 20 & 10 \\
\hline & Presentase & & $66,67 \%$ & $33,33 \%$ \\
\hline
\end{tabular}


Dari tabel 3 di atas hasil siklus 1 jumlah anak yang tuntas atau mendapat $\geq 60$ sebanyak 20 siswa atau sebesar $66,67 \%$ sedangkan yang belum tuntas sebanyak 10 siswa atau sebesar 33,33\%, serta nilai rata-rata kelas hanya mencapai 62,5 .

Tabel 4

Hasil Belajar Siswa

\begin{tabular}{|c|c|c|c|c|}
\hline \multirow[b]{2}{*}{ No } & \multirow[b]{2}{*}{ Nama } & \multirow{2}{*}{$\begin{array}{l}\text { Nilai } \\
\text { Siklus } 2\end{array}$} & \multicolumn{2}{|c|}{ Ketuntasan } \\
\hline & & & Tuntas & $\begin{array}{l}\text { Tidak } \\
\text { Tuntas }\end{array}$ \\
\hline 1 & Aprianto & 80 & $\sqrt{ }$ & \\
\hline 2 & Aldi & 75 & $\sqrt{ }$ & \\
\hline 3 & Arafik & 80 & $\sqrt{ }$ & \\
\hline 4 & Ahmad & 100 & $\sqrt{ }$ & \\
\hline 5 & Aliah & 80 & $\sqrt{ }$ & \\
\hline 6 & Ajai Gustian & 75 & $\sqrt{ }$ & \\
\hline 7 & Della & 100 & $\sqrt{ }$ & \\
\hline 8 & Dafid & 85 & $\sqrt{ }$ & \\
\hline 9 & Defri & 70 & $\sqrt{ }$ & \\
\hline 10 & Dimas & 80 & $\sqrt{ }$ & \\
\hline 11 & Elmansyah & 55 & & $\sqrt{ }$ \\
\hline 12 & Elmarani & 75 & $\sqrt{ }$ & \\
\hline 13 & Edi Santoso & 60 & $\sqrt{ }$ & \\
\hline 14 & Firdaus & 75 & $\sqrt{ }$ & \\
\hline 15 & Frem Kusumo & 75 & $\sqrt{ }$ & \\
\hline 16 & Firmansyah & 85 & $\sqrt{ }$ & \\
\hline 17 & Holid & 100 & $\sqrt{ }$ & \\
\hline 18 & Intan & 90 & $\sqrt{ }$ & \\
\hline 19 & Putri Jelita & 70 & $\sqrt{ }$ & \\
\hline 20 & Pina Anvaim & 100 & $\sqrt{ }$ & \\
\hline 21 & Rizki & 95 & $\sqrt{ }$ & \\
\hline 22 & M. Sandi & 90 & $\sqrt{ }$ & \\
\hline 23 & Redi Yansyah & 60 & $\sqrt{ }$ & \\
\hline 24 & Sri Yuyun & 55 & & $\sqrt{ }$ \\
\hline 25 & Shinta Bella & 70 & $\sqrt{ }$ & \\
\hline 26 & Samsiah & 90 & $\sqrt{ }$ & \\
\hline 27 & Selci & 75 & $\sqrt{ }$ & \\
\hline 28 & Verdi & 90 & $\sqrt{ }$ & \\
\hline 29 & Tina Lestari & 100 & $\sqrt{ }$ & \\
\hline \multirow[t]{5}{*}{30} & Wahyu & 90 & $\sqrt{ }$ & \\
\hline & Jumlah & 2425 & & \\
\hline & Rata-rata Kelas & 80,83 & & \\
\hline & Nilai Terendah & 55 & & \\
\hline & Nilai Tertinggi & 100 & & \\
\hline
\end{tabular}




\begin{tabular}{lllll}
\hline \multirow{2}{*}{ Tuntas } & Jumlah Anak & 30 & 28 & 2 \\
\cline { 2 - 5 } & Presentase & $93,33 \%$ & $6,67 \%$ \\
\hline
\end{tabular}

Dari tabel 4 di atas hasil siklus 2 jumlah anak yang tuntas atau mendapat $\geq 60$ sebanyak 28 siswa atau sebesar 93,33\% sedangkan yang belum tuntas sebanyak 2 siswa atau sebesar 6,67\%, serta nilai rata-rata kelas hanya mencapai 80,83. Dari uraian di atas dapat digabungkan Hasil Evaluasi Persiklus Seperti pada Tabel berikut:

Tabel 5

Hasil Belajar Siswa

\begin{tabular}{|c|c|c|c|c|}
\hline \multirow{2}{*}{ No } & \multirow{2}{*}{ Nama } & \multicolumn{3}{|l|}{ Nilai } \\
\hline & & Prasiklus & Siklus 1 & Siklus 2 \\
\hline 1 & Aprianto & 65 & 65 & 80 \\
\hline 2 & Aldi & 45 & 45 & 75 \\
\hline 3 & Arafik & 40 & 70 & 80 \\
\hline 4 & Ahmad & 70 & 85 & 100 \\
\hline 5 & Aliah & 35 & 70 & 80 \\
\hline 6 & Ajai Gustian & 25 & 55 & 75 \\
\hline 7 & Della & 75 & 75 & 100 \\
\hline 8 & Dafid & 65 & 65 & 85 \\
\hline 9 & Defri & 50 & 50 & 70 \\
\hline 10 & Dimas & 75 & 75 & 80 \\
\hline 11 & Elmansyah & 25 & 35 & 55 \\
\hline 12 & Elmarani & 35 & 50 & 75 \\
\hline 13 & Edi Santoso & 45 & 45 & 60 \\
\hline 14 & Firdaus & 50 & 65 & 75 \\
\hline 15 & Frem Kusumo & 65 & 65 & 75 \\
\hline 16 & Firmansyah & 25 & 55 & 85 \\
\hline 17 & Holid & 60 & 60 & 100 \\
\hline 18 & Intan & 75 & 75 & 90 \\
\hline 19 & Putri Jelita & 40 & 40 & 70 \\
\hline 20 & Pina Anvaim & 75 & 80 & 100 \\
\hline 21 & Rizki & 65 & 75 & 95 \\
\hline 22 & M. Sandi & 35 & 65 & 90 \\
\hline 23 & Redi Yansyah & 45 & 45 & 60 \\
\hline 24 & Sri Yuyun & 25 & 50 & 55 \\
\hline 25 & Shinta Bella & 70 & 70 & 70 \\
\hline 26 & Samsiah & 70 & 70 & 90 \\
\hline 27 & Selci & 50 & 60 & 75 \\
\hline 28 & Verdi & 40 & 70 & 90 \\
\hline 29 & Tina Lestari & 60 & 75 & 100 \\
\hline \multirow[t]{5}{*}{30} & Wahyu & 55 & 70 & 90 \\
\hline & Jumlah & 1555 & 1875 & 2425 \\
\hline & Rata-rata Kelas & 51,83 & 62,5 & 80,83 \\
\hline & Nilai Terendah & 25 & 35 & 55 \\
\hline & Nilai Tertinggi & 75 & 85 & 100 \\
\hline
\end{tabular}




\begin{tabular}{lllll}
\hline \multirow{2}{*}{ Tuntas } & Jumlah Anak & 13 & 20 & 28 \\
\cline { 2 - 5 } & Presentase & $43,33 \%$ & $66,67 \%$ & $93,33 \%$ \\
\hline
\end{tabular}

Berdasarkan tabel 5 terlihat hasil belajar siswa dalam pembelajaran IPA tentang proses pembentukan tanah karena pelapukan batuan dengan menggunakan model kooperatif tipe Two Stay Two Stray menunjukkan peningkatan hasil belajar dari satu siklus ke siklus berikutnya. Hasil belajar sebelum perbaikan pembelajaran, jumlah siswa yang mencapai ketuntasan belajar hanya 13 orang $(43,33 \%)$ dengan nilai rata-rata kelas 51,83 , pada siklus 1 siswa yang mencapai ketuntasan belajar sebanyak 20 orang $(66,67 \%)$ dengan nilai rata-rata kelas 62,5 dan pada siklus 2 persentase ketuntasan siswa meningkat menjadi 93,33\% atau sebanyak 28 siswa dengan nilai rata-rata kelas sebesar 80,83 . Dengan demikian pelaksanaan perbaikan pembelajaran IPA sudah dapat dikatakan berhasil karena sudah memenuhi syarat ketuntasan minimal klaksikal yaitu $85 \%$ siswa yang mencapai nilai $\geq 60$. Peningkatan ketuntasan hasil belajar siswa dari prasiklus dan setelah perbaikan pembelajaran pada siklus 1 dan siklus 2 secara lebih jelas dapat dilihat pada diagram 2 di bawah ini.

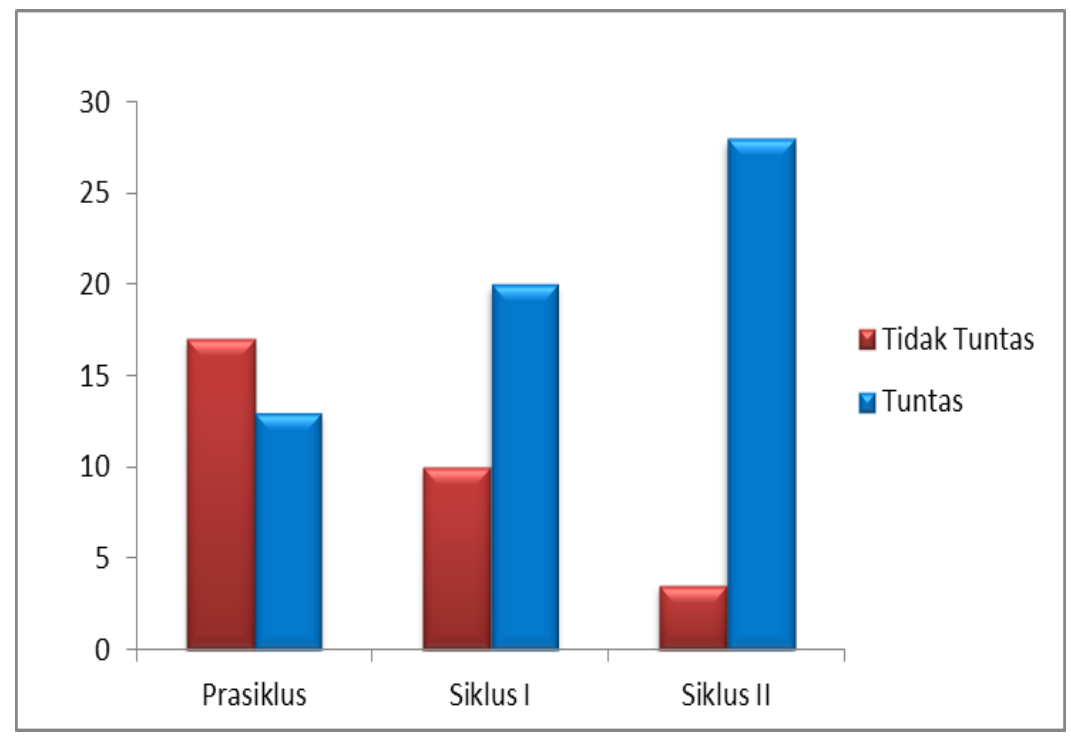

Gambar 2. Peningkatan Ketuntasan Hasil Belajar Siswa

\section{PEMBAHASAN}

Dari hasil penelitian dan evaluasi pembelajaran IPA Kelas V SD Negeri 39 Lubuklinggau sebelum perbaikan menunjukkan bahwa tingkat keaktifan siswa dalam kegiatan pembelajaran prasiklus yang terlibat secara aktif hanya 17 orang, yang 
memperoleh nilai $\geq 60$ hanya 13 orang atau 43,33\%. Hal ini menunjukkkan bahwa aktivitas dan hasil belajar siswa kurang memuaskan dan belum memenuhi target yang diinginkan. Dari hasil refleksi terhadap pembelajaran yang telah dilakukan dan kemudian didiskusikan dengan supervisor 2 ditemukakan bahwa pembelajaran sulit dipahami dan diterima oleh siswa. Selain itu hasil belajar siswa tergolong rendah yaitu nilai rata-rata kelas 51,83. Hal ini disebabkan metode pembelajaran yang digunakan oleh guru kurang bervariasi dan cenderung monoton sehingga siswa merasa jenuh.Proses pembelajaran berikutnya dilaksanakan melalui Penelitian Tindakan Kelas yang dilakukan dalam 2 siklus, antara lain:

Pada pembelajaran siklus 1 dilakukan upaya perbaikan dengan menggunakan model pembelajaran kooperatif tipe Two Stay Two Stray. Hasil observasi dan evaluasi pada siklus 1 menunjukan adanya peningkatan aktivitas dan hasil belajar siswa. Siswa yang terlibat aktif dalam pembelajaran siklus 1 sebanyak 21 orang $(70 \%)$ dan 20 orang $(66,67 \%)$ memperoleh nilai $\geq 60$. Walaupun telah menunjukkan peningkatan, baik aktivitas maupun hasil belajar siswa namun belum dapat dikatakan berhasil karena belum mencapai target ketuntasan dan keaktifan klaksikal. Hasil observasi dan refleksi terhadap pembelajaran siklus 1 diperoleh temuan bahwa model pembelajaran yang digunakan belum efektif dalam pelaksanaannya karena siswa belum terbiasa dengan model pembelajaran tersebut.

Berdasarkan refleksi hasil pembelajaran pada siklus 1 maka perlu dilakukan perbaikan pembelajaran pada siklus 2 dengan menggunakan model pembelajaran kooperatif tipe Two Stay Two Stray. Pada kegiatan pembelajaran siklus 2 penggunaan model pembelajaran kooperatif tipe Two Stay Two Stray lebih ditingkatkan lagi keefektifannya sehingga sebagian besar aktivitas dan hasil belajar siswa menjadi meningkat. Siswa yang terlibat aktif dalam pembelajaran sebanyak 26 orang $(86,67 \%)$. Sedangkan siswa yang memperoleh nilai $\geq 60$ sebanyak 28 orang $(93,33 \%)$ dengan nilai rata-rata kelas mencapai 80,83 . Hal ini menunjukkan bahwa perbaikan pembelajaran pada siklus sudah dikatakan berhasil, karena aktivitas dan hasil belajar siswa sudah mencapai target ketuntasan keaktifan klaksikal $\geq 80 \%$ dan nilai rata-rata kelas $\geq 60$ serta ketuntasan belajar klaksikal $\geq 85 \%$. Berdasarkan uraian di atas baik dari siklus 1 maupun siklus 2 dengan menggunakan penggunaan model pembelajaran kooperatif tipe Two Stay Two Stray dalam perbaikan pembelajaran, dapat disimpulkan bahwa penggunaan model pembelajaran kooperatif tipe Two Stay Two Stray dapat meningkatkan hasil belajar IPA siwa kelas VI pada materi proses pembentukan tanah karena pelapukan batuan. 


\section{SIMPULAN}

Model pembelajaran kooperatif tipe Two Stay Two Stray dapat meningkatkan hasil belajar siswa pada materi proses pembentukan tanah karena pelapukan batuan, peningkatan ini terlihat dari hasil belajar siswa pada prasiklus siswa tuntas sebanyak 13 orang $(43,33 \%)$ meningkat pada siklus 1 sebanyak 20 orang $(66,67 \%)$ dan pada siklus meningkat menjadi 28 orang $(93,33 \%)$.

Model pembelajaran kooperatif tipe Two Stay Two Stray juga dapat meningkatkan keaktifan dan keterlibatan siswa dalam proses pembelajaran. Hal ini terlihat dari keaktifan siswa pada prasiklus hanya 17 orang $(56,67 \%)$ siswa yang aktif, pada siklus 1 meningkat menjadi 21 orang (70\%) dan pada siklus 2 berhasil mencapai 26 orang $(86,67 \%)$.

\section{DAFTAR PUSTAKA}

Hanafiah, N \& Suhana, C. (2009). Konsep Strategi pembelajaran. Bandung: PT. Refika Aditama.

Khaliq. (2009). Cakrawala Pendidikan. Jakarta : Indonusa.

Pribadi, B. (2009). Model Desain Sistem Pembelajaran. Jakarta: Dian Rakyat. Rusman. (2010). Model-Model Pembelajaran. Jakarta: Raja Grafindo Persada. Suprijono, A. (2009). Cooperative Learning. Yogyakarta: Pustaka Belajar. 